\title{
Flux and fate of river-discharged sediments to the Adriatic Sea
}

\author{
John D. Milliman, ${ }^{1,2}$ Davide Bonaldo, ${ }^{2 *}$ Sandro Carniel $^{2}$
}

${ }^{1}$ School of Marine Science, College of William and Mary, 1375 Greate Road, Gloucester Point 23062-1346, VA, USA; ${ }^{2}$ Institute of Marine Sciences, National Research Council of Italy, Castello 2737/F, 30122 Venice, Italy

*Corresponding author: davide.bonaldo@ve.ismar.cnr.it

\begin{abstract}
Small rivers, particularly those draining mountainous terrain, discharge disproportionately large quantities of sediment to the global ocean. Because small mountainous rivers are more susceptible to catastrophic events, they tend to discharge their sediments over relatively short periods of time, such as during floods. The impact of small mountainous rivers is especially evident on the coastal ocean, such as the Adriatic Sea where fully $75 \%$ of the estimated 145 million tons (Mt) of discharged sediment comes from rivers with basin areas smaller than $7000 \mathrm{~km}^{2}$. Within this semi-enclosed basin in the northeast of the Mediterranean Sea, of particular note are the high sediment loads of five Albanian rivers (located in the southeast), which, prior to dam construction, collectively discharged about $85 \mathrm{Mt}$ $\mathrm{yr}^{-1}$ perhaps much of it at hyperpycnal concentrations, which would have allowed the sediment to bypass the shelf and be deposited at greater depths. Geochemical data confirm that Albanian river sediment extends well into the southern and central Adriatic Sea. Delineating and understanding the flux and fate of Adriatic Sea sediments may be best facilitated through the reanalysis of existing river datasets and the acquisition of new river data, particularly during periodic floods, high-resolution seismic profiling coupled with sitespecific coring, as well as application of integrated ocean-sediment numerical models.
\end{abstract}

Key words: Adriatic Sea; river discharge; sediments; river sediment fate; Albania.

Received: March 2016. Accepted: June 2016.

\section{INTRODUCTION}

Prior to the proliferation of large dams in the second half of the $20^{\text {th }}$ century, global rivers on average delivered about 19 billion tons (bt) of sediment annually to the ocean (Milliman and Farnsworth, 2011), the volumetric equivalent of about 15 or 16 Great Walls of China entering the ocean each year. One might assume that large rivers would be the dominant source for these sediments. The Amazon and Ganges-Brahmaputra (1.2 bt $\left.\mathrm{yr}^{-1}\right)$ and Yangtze and Mississippi rivers (0.4-0.5 $\left.\mathrm{bt} \mathrm{yr}^{-1}\right)$, for example, prior to river damming, were responsible for about $15 \%$ of the total global sediment flux. However, there is an increasing realization that smaller mountainous rivers discharge far more sediment than their drainage basin areas would suggest (Milliman and Syvitski, 1992; Syvitski and Milliman, 2007). If one normalizes the annual sediment load by dividing it by the river's basin area (sediment yield), the Amazon River (basin area 6,300,000 $\mathrm{km}^{2}$ ) and the pre-dam Mississippi (basin area 3,300,000 $\mathrm{km}^{2}$ ) had annual sediment yields of $\sim 190 \mathrm{t} \mathrm{km}^{-2} \mathrm{yr}^{-1}$ and $\sim 130 \mathrm{t} \mathrm{km}^{-2} \mathrm{yr}^{-1}$, respectively. Other examples can be found of large rivers characterized by even smaller sediment yields, such as the Parana-Paraguay system (Argentina), where a basin spanning $2.6 \times 10^{6} \mathrm{~km}^{2}$ surface area has an annual sediment yield of $\sim 50 \mathrm{t} \mathrm{km}^{-2} \mathrm{yr}^{-1}$ (Guerrero et al., 2015).
In contrast to these large rivers, 14 small rivers on the island of Java, whose combined basin areas total 52,000 $\mathrm{km}^{2}$, discharge about 100 million tons of sediment annually (Milliman et al., 1999), which equates to an average sediment yield of $2000 \mathrm{t} \mathrm{km}^{-2} \mathrm{yr}^{-1}$. Even more impressive are 22 Taiwanese rivers (drainage basin areas totaling $25,000 \mathrm{~km}^{2}$ ) that collectively discharge $200 \mathrm{Mt} \mathrm{yr}^{-1}$ (Kao and Milliman, 2008; Milliman and Farnsworth, 2011, p. 307 ), equating to a sediment yield of $8000 \mathrm{t} \mathrm{km}^{-2} \mathrm{yr}^{-1}, 40$ fold greater than that of the Amazon.

Globally there are 18 rivers with basin areas greater than $1,000,000 \mathrm{~km}^{2}$, compared to an estimated 4000 rivers with basin areas between 1000 and $10,000 \mathrm{~km}^{2}$. Given their sheer number plus their often high sediment yields, small rivers collectively can have a disproportionately great effect on sediment flux to the global ocean, an effect that often has been underappreciated. Small mountainous rivers, that is rivers with basin areas less than $10,000 \mathrm{~km}^{2}$ and draining mountains higher than $1000 \mathrm{~m}$ (Milliman and Syvitski, 1992), account for about $10 \%$ of the land area draining into the global ocean, but collectively they account for about $15 \%$ of the annual water discharge and $45 \%$ and $30 \%$ of the suspended and dissolved solids reaching the ocean annually (Table 2.13 in Milliman and Farnsworth, 2011).

Small mountainous rivers are also much more likely to have suspended sediment concentrations at hyperpyc- 
nal levels, that is $>40 \mathrm{~g} \mathrm{~L}^{-1}$. When hyperpycnal river waters enter the ocean they are sufficiently dense to sink and carry the sediment across the shelf and into deeper water (Mulder and Syvitski, 1995). Drake et al. (1972), for instance, found turbidite deposits in the adjacent Santa Barbara Basin that had been deposited only a few weeks after the 1969 flood of the Santa Clara River mentioned above; similarly, Mulder et al. $(1998,2003)$ found turbidite deposits seaward of the Var River in southern France following a major flood.

There are several reasons why small mountainous rivers have high sediment yields. With elevations higher than $1000 \mathrm{~m}$ and with steep gradients, together with relatively small flood plains, small-river basins experience high rates of erosion but have relatively little accommodation space in which the eroded sediment can be stored. Moreover, small-river basins are more responsive to episodic events, such as earthquakes or floods. Large river basins such as the Amazon or Mississippi can modulate a local storm or flood; the maximum measured discharge of the Amazon, for instance, is only about twice its average discharge (Fig. 3.45 in Milliman and Farnsworth, 2011). Heavy rainfalls over small watersheds, in contrast, often can generate short-lived and flashy events. A typhoon-generated flood on the Choshui River (Taiwan) in July 2001, for instance, lasted only a few hours, but its peak discharge was $28,000 \mathrm{~m}^{3} \mathrm{sec}^{-1}$, about 3 orders of magnitude greater than the river's flow before or after the flood. Such short-lived flashy floods, in fact, are responsible for more than $70 \%$ of the sediment discharge in most Taiwanese rivers (Kao and Milliman, 2008). Such events do not only occur in typhoon-prone areas, however. During several heavy rainstorms in the winter of 1969 , for instance, the Santa Clara River, a small $\left(4100 \mathrm{~km}^{2}\right.$ basin area) semi-arid river about $80 \mathrm{~km}$ north of Los Angeles, discharged $45 \mathrm{Mt}$ of sediment, $18 \mathrm{Mt}$ on one day (Fig. 1); most of the discharge occurred at hyperpycnal concentrations, peak concentrations exceeding $160 \mathrm{~g} \mathrm{~L}^{-1}$ (Waananen, 1969; Warrick and Milliman, 2003). Over the preceding 20 years, when rainfall was sparse and there were no floods, the Santa Clara discharged only about 15 Mt in total. In contrast to the $18 \mathrm{Mt}$ discharged by the Santa Clara on a single day, during a peak flood year in 1950 the Mississippi River $\left(3,300,000 \mathrm{~km}^{2}\right.$ basin area) discharged more than $500 \mathrm{Mt}$ of sediment, but daily sediment loads never exceeded 5 Mt (Fig. 1); moreover, suspended sediment concentrations never reached $1 \mathrm{~g} \mathrm{~L}^{-1}$.

Within the Mediterranean basin, the Adriatic Sea represents a paradigmatic test site for investigating the role of small mountain rivers in the sediment budget of a relatively small, semi-enclosed basin, and their contribution to mass and nutrient fluxes off the continental shelf. With reference to this site, the present paper aims at providing some preliminary estimates for this process, assessing the main sources of uncertainty and suggesting possible strategies for filling this information gap.

\section{SEDIMENT DISCHARGE TO THE ADRIATIC SEA}

The Adriatic Sea is a NW-SE-trending semi-enclosed basin within the northern Mediterranean Sea, approximately $200 \mathrm{~km}$ in width and $800 \mathrm{~km}$ in length (Fig. 2). Its northernmost area is constituted by a gently sloping continental shallow shelf, depths on the order of a few tens of meters, which is occasionally exposed to intense cold winds, spanning from the Gulf of Venice to Ancona (Fig. 2). The broad, shallow northern sub-basin is interrupted south of Ancona by the Pomo Pit, a depression crossing the basin along its SW-NE axis that reaches bottom depths from 150 to $280 \mathrm{~m}$. To the southeast off the Apulian and Albanian coasts, the shelf dips into the South Adriatic Pit (SAP), the deepest region in the Adriatic Sea at $1200 \mathrm{~m}$. The SAP is connected by the Palagruža Sill $(180 \mathrm{~m})$ by the Middle Adriatic Pit to the north, while the limit between the Adriatic Sea proper and the deeper Ionian Sea is defined by the Otranto Strait sill $(780 \mathrm{~m})$ to the

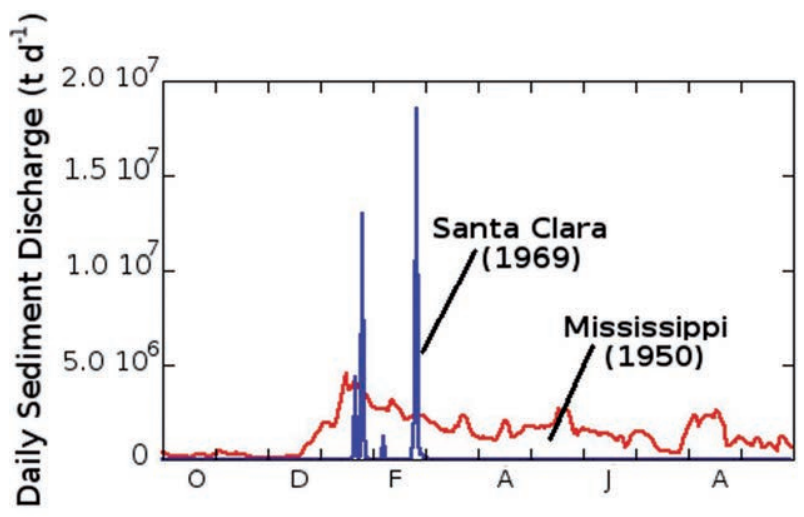

Fig. 1. Daily sediment discharges from the Santa Clara (blue) and the Mississippi (red) rivers during their record discharge years, 1969 and 1950, respectively. Two flash floods, each lasting a total about 3-4 days, in the winter of 1969 accounted for 98\% (45 Mt) of the Santa Clara River's annual sediment load, nearly all at hyperpycnal concentrations $(>40 \mathrm{~g} / \mathrm{L})$. Peak daily discharge was 18 Mt; daily discharge for the remaining 358 days ranged from 0 (when the river was dry) to 200,000 tons. The Mississippi River in 1950, by contrast, discharged about $500 \mathrm{Mt}$, daily discharge averaging more than $1 \mathrm{Mt}$ but never exceeding $4.5 \mathrm{Mt}$; sediment concentrations never reached $1 \mathrm{~g} / \mathrm{L}$. Reprinted from: J.D. Milliman and K.L. Farnsworth KL, 2011. River discharge to the coastal ocean: a global synthesis. Cambridge University Press; this figure cannot be reproduced, shared, altered, or exploited commercially in any way without the permission of Cambridge University Press, as it is copyrighted material and therefore not subject to the allowances permitted by an Open Access licence. 
south. Being an interface between the Mediterranean and the Adriatic basins, the southern Adriatic margin (SAM) acts as a cold engine for regional circulation, and thus serves as a crossroads for a variety of hydrodynamic, geological and biological processes (Carniel et al., 2016a).

Few coastal seas in the world are as dominated by as many small mountainous rivers as the Adriatic Sea: Alpine rivers (the Po, Adige, Brenta, Piave and Tagliamento rivers) to the northwest, Apennine rivers to the west, and Albania mountainous rivers in the southeast. In total we count 35 rivers draining into the Adriatic basin (Fig. 3), for which we have suspended sediment data for 29 rivers (see p. 241-247 in Milliman and Farnsworth, 2011). The Po River is by far the largest Adriatic river, draining $74,000 \mathrm{~km}^{2}$ and having an average flow of 1500 $\mathrm{m}^{3} \mathrm{~s}^{-1}$; if one includes the Drini (Albania; 20,000 $\mathrm{km}^{2}$ ) and the Adige (northeast Italy; $12,000 \mathrm{~km}^{2}$ ), collectively these three rivers drain $~ 60 \%$ of the $173,000 \mathrm{~km}^{2}$ drained by the 35 Adriatic rivers. Headwaters in 11 of these rivers - notably those draining Italian Alps plus the Albanian rivers - lie at elevations $>2000 \mathrm{~m}$, the Po being by far the highest at $4800 \mathrm{~m}$. In contrast, 19 of the 35 rivers have basin areas less than $1500 \mathrm{~km}^{2}$, and 11 have headwaters lower than $1000 \mathrm{~m}$ in elevation; 8 of those rivers drain Italy's Apennines. Viewing the 35 Adriatic rivers in total, sediment discharge from Italian rivers shows a positive log-linear relationship with basin area, there being apparently little difference in sediment yield between lower and higher elevation rivers (Fig. 4; blue diamonds). Albanian rivers, in contrast, have much higher sediment loads relative to basin area. The Shkumbini River $\left(2200 \mathrm{~km}^{2}\right)$, for

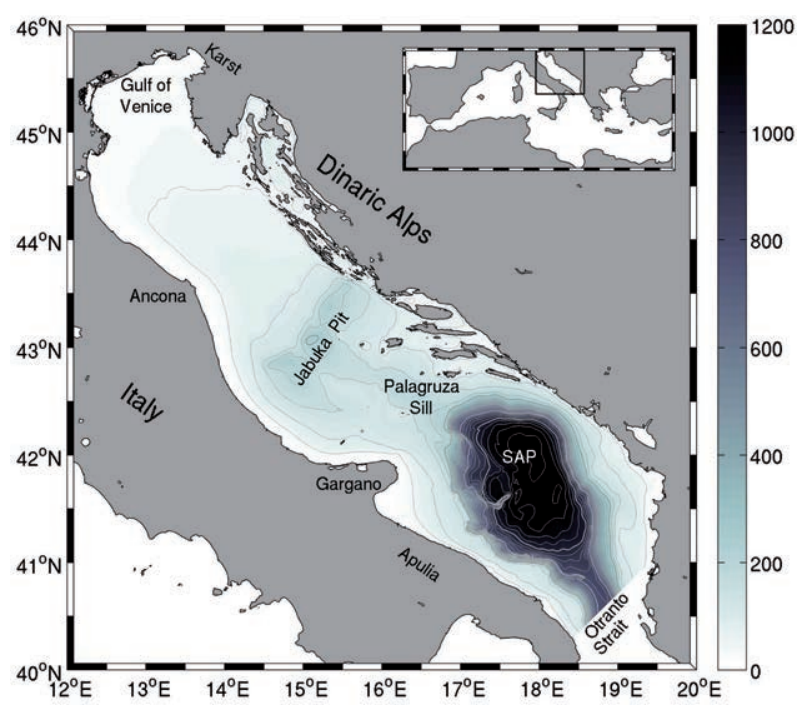

Fig. 2. Adriatic Sea bathymetry and main sites discussed in the text. instance, has a sediment load of 7.2 $\mathrm{Mt} \mathrm{yr}^{-1}$, whereas the Apennine Ofanto River (2700 $\mathrm{km}^{2}$ basin area) has an average sediment load of $0.9 \mathrm{Mt} \mathrm{yr}^{-1}$. More impressive are the $30 \mathrm{Mt} \mathrm{yr}^{-1}$ discharged by the Albanian Semani River $\left(5600 \mathrm{~km}^{2}\right)$; in comparison, the Adige in northern Italy (basin area $12,000 \mathrm{~km}^{2}$ ) discharges only $1.6 \mathrm{Mt} \mathrm{yr}^{-1}$. The high Albanian sediment loads and yields, we assume, reflect heavy rains and resulting flashy floods, frequent earthquakes and land use. Trincardi et al. (1994) and Syvitski and Kettner (2007), as well as the database in Milliman and Farnsworth, 2011 (see Table C8), have estimated that prior to dam construction the northern Italian rivers collectively discharged 34-45 million tons of sediment annually $\left(\mathrm{Mt} \mathrm{yr}^{-1}\right)$ to the Adriatic. Considering the five Alpine rivers alone (Fig. 3), we estimate that prior to

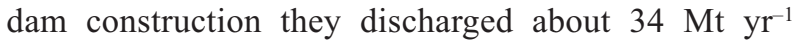
(Fig. 4). In addition, Apennine rivers discharge another $22 \mathrm{Mt} \mathrm{yr}^{-1}$, leading to a total of about $56 \mathrm{Mt} \mathrm{yr}^{-1}$ of sediment discharged to the western side of the Adriatic Sea prior to dams (Milliman and Farnsworth, 2011).

Of greater sedimentological importance are five main Albanian rivers, four of which have headwaters at elevations higher than $2000 \mathrm{~m}$. Collectively, prior to dam construction, these five rivers discharged an estimated $85 \mathrm{Mt}$ $\mathrm{yr}^{-1}$, the Vijose and Semani rivers each discharging more than $25 \mathrm{Mt} \mathrm{yr}^{-1}$ (Simeoni et al., 1997; Ciavola et al., 1999) (Fig. 5). Based on available data, Mulder and Syvitski (1995) listed Albania's Drini River as a potentially hyperpycnal river; but with further data, we now can include the pre-dammed Semani and Vijose rivers (sediment concentrations 10 and $5 \mathrm{mg} \mathrm{L}^{-1}$, respectively; see p. 247 in Milliman and Farnsworth, 2011) as capable of discharging suspended sediment at hyperpycnal levels. With the exception of the Neretva River $\left(14 \mathrm{Mt} \mathrm{yr}^{-1}\right.$; Eurosion, 2004), Croatian rivers, which in large part drain limestone terrain, discharge relatively little sediment to the Adriatic. Prior to dam construction, Italian, Croatian and Albanian rivers therefore discharged about $145 \mathrm{Mt}$ $\mathrm{yr}^{-1}$ of sediment to the Adriatic Sea. In terms of basin size, the three large rivers (Po, Adige and Drini) would have accounted for only $25 \%$ of the sediment discharged to the Adriatic (15, 12 and $16 \mathrm{Mt} \mathrm{yr}^{-1}$, respectively). The remaining $75 \%$ of the Adriatic's sediment input came from 32 rivers, their drainage basins all being less than $7000 \mathrm{~km}^{2}$ in area. Albanian rivers contributed about $60 \%$ of the total sediment entering the Adriatic (Fig. 3); this flux, however, has declined with the construction of dams (Simeoni et al., 1997; Milliman and Farnsworth, 2011) and probably will continue to decline with the future construction of more dams (Bethge, 2014). One can therefore view the Adriatic is having abundant sediment discharge to the southeastern and northwestern parts of the basin compared to relatively little discharge to the central sections of the basin. 


\section{PROBLEMATIC SEDIMENT DISCHARGE DATA}

The sediment loads presented in Figs. 4 and 5 are, at best, estimates of values prior to the dam construction that occurred largely in the latter decades of the $20^{\text {th }}$ century. With few exceptions, such as the Po River, the database is difficult to access, suggesting that, among other things, the data for many, perhaps most, rivers may be sparse in terms of valid observations and/or number of years of measurement. This problem is particularly critical for rivers in which annual discharge varies widely, such as those rivers subject to periodic flash floods. Sudden, short-lived flash floods can raise the river flow an order of magnitude or more within a few hours - and decline almost as quickly (Warrick and Milliman, 2003; Milliman and Kao, 2005). Being a non-linear function of water discharge, suspended sediment concentration and thus sediment discharge can increase by one to three orders of magnitude. Monitoring flash floods, however, is extremely difficult, and only a few have ever been adequately monitored. Often sediment rating curves during such events may have been based on one or two sediment samples which are then compared to daily water discharge, and using the resulting rating curve, daily sediment discharge could be computed (Inman and Jenkins, 1999). The problem with this approach is that both peak sediment concentration and water discharge can vary greatly hour-to-hour and by an order of magnitude or more within $24 \mathrm{~h}$.

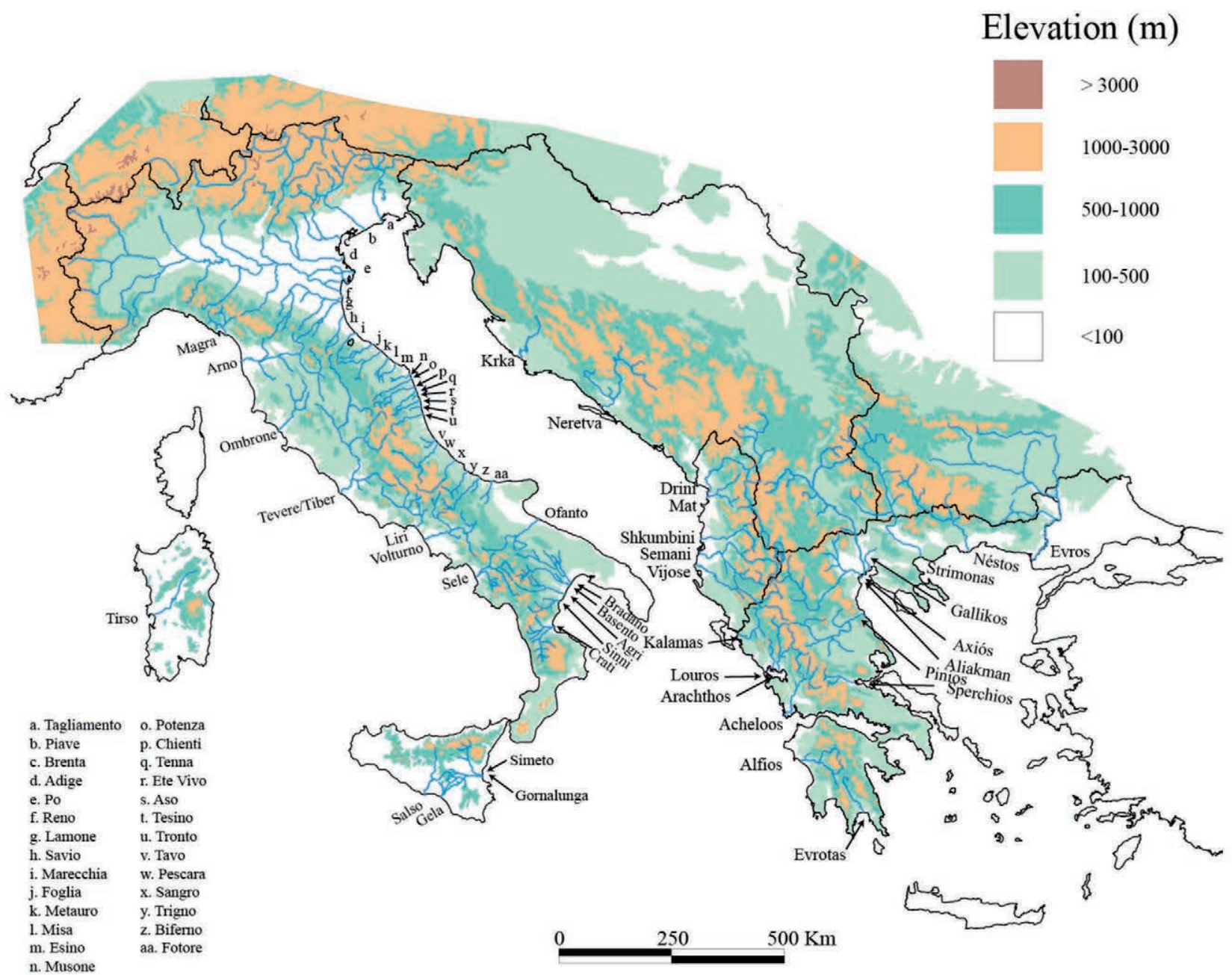

Fig. 3. Adriatic Sea and the 35 discharging rivers for which there are published data. Reprinted from: J.D. Milliman and K.L. Farnsworth KL, 2011. River discharge to the coastal ocean: a global synthesis. Cambridge University Press; this figure cannot be reproduced, shared, altered, or exploited commercially in any way without the permission of Cambridge University Press, as it is copyrighted material and therefore not subject to the allowances permitted by an Open Access licence. 


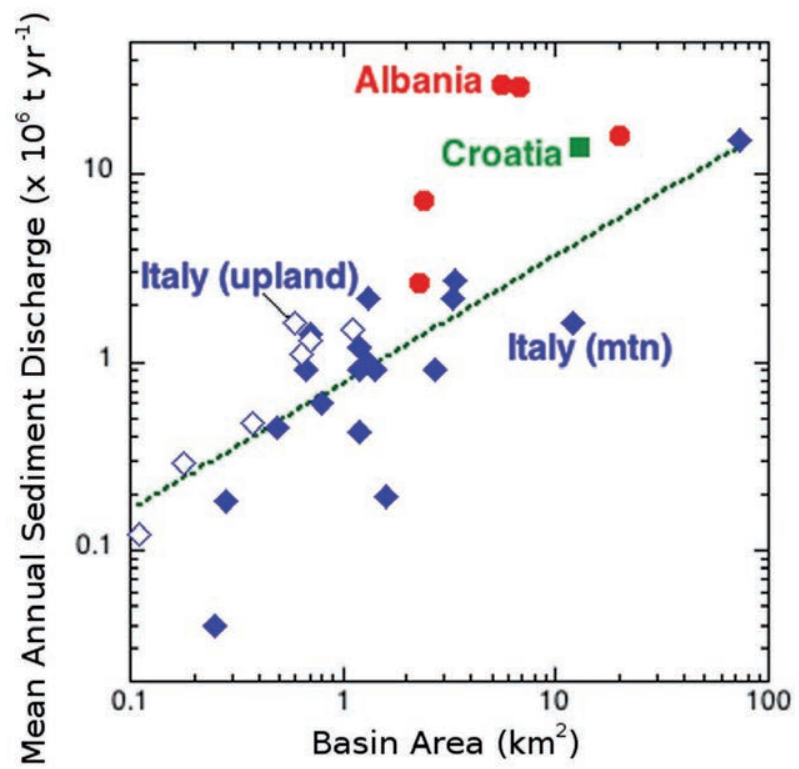

Fig. 4. Mean annual suspended sediment loads vs basin areas for 29 rivers that discharge into the Adriatic Sea; we have found no sediment discharge data for the other 6 Adriatic rivers. Upland and mountain (mtn) rivers have basins with 500-1000 m and 1000-3000 m average height respectively. Data compiled by: J.D. Milliman and K.L. Farnsworth KL, 2011. River discharge to the coastal ocean: a global synthesis. Cambridge University Press; this figure cannot be reproduced, shared, altered, or exploited commercially in any way without the permission of Cambridge University Press, as it is copyrighted material and therefore not subject to the allowances permitted by an Open Access licence.

\section{Elevation (m)}

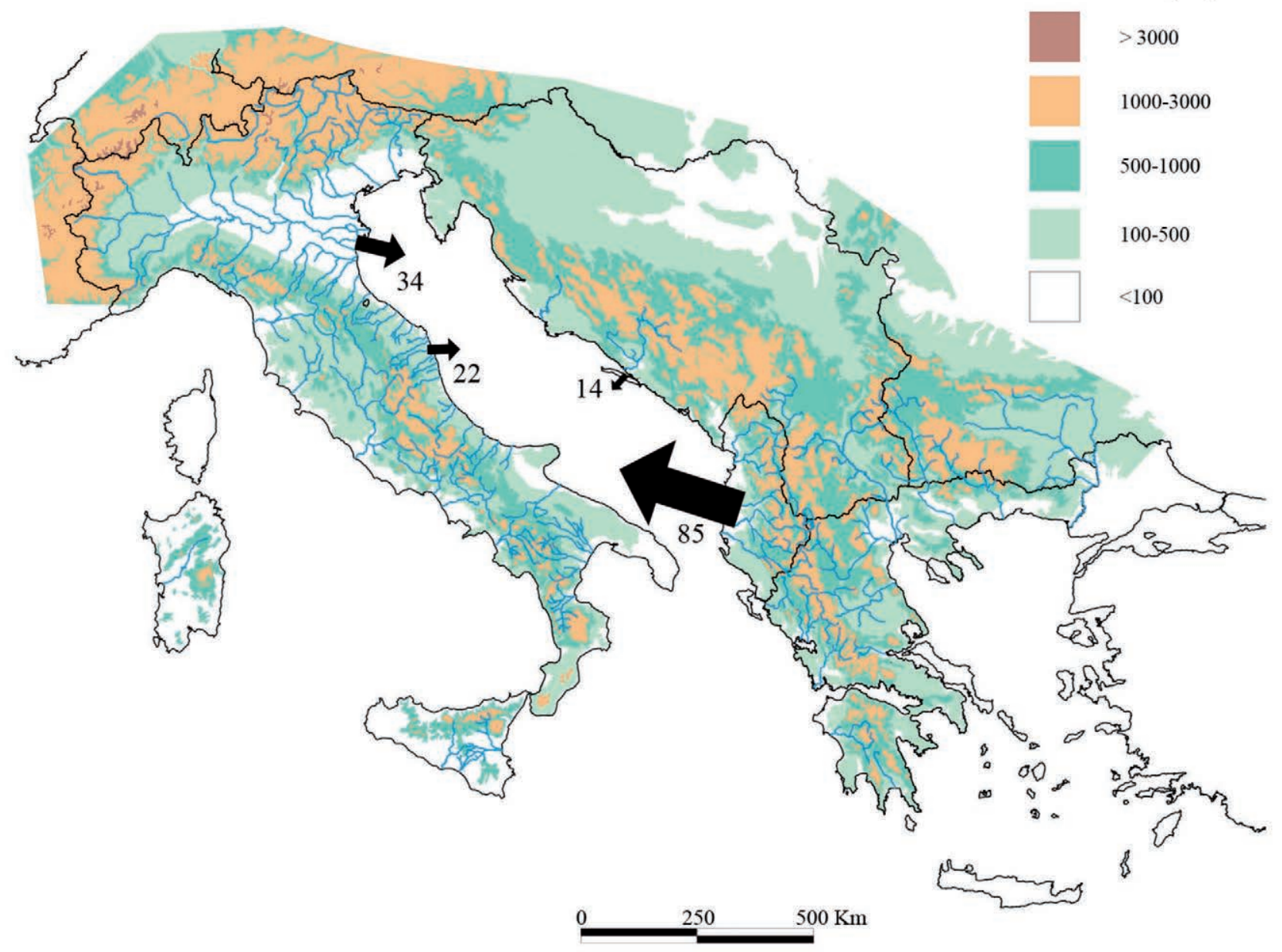

Fig. 5. Mean annual (pre-dam) sediment flux to the Adriatic Sea from rivers draining the Italian Alps (5 rivers), Italian Apennines (24 rivers), Croatia (1 river) and Albania (5 rivers). Sediment loads are in millions of tons per year; arrows are proportional to the loads. 
Comparing daily and hourly water discharge data rather than hourly discharge data - in calculating sediment loads (Fig. 6) shows that during flashy floods, the actual sediment load can be underestimated by $80 \%$ or more. Over longer term floods, such as caused by snow-melt, calculated sediment loads using daily discharge approach those using hourly discharge (Fig. 6). Not knowing how sediment discharges were measured in many Italian or (particularly) Albanian rivers, especially during flash floods (Selenica, 2004; De Luque et al., 2006), the discharges shown in Fig. 5 can only be considered as estimates. Albanian river sediment discharge, in fact, may be significantly greater than previously reported. Reliable sediment concentrations data are particularly critical to determine if river waters reached hyperpycnal concentrations. Considering their generally higher sediment concentrations (Fig. 4) and the probable flashiness of their floods, it seems likely that such hyperpycnal events would occur in Albanian rivers rather than in Italian rivers whose sediment concentrations tend to be lower (Fig. 4) and flashy events are fewer.

\section{FATE OF SEDIMENT DISCHARGE IN THE ADRIATIC}

Extensive study of the Italian continental shelf and upper continental slope indicates that, with the fluctuation of Quaternary sea level, the many Italian western-flowing rivers - with the possible exception of the Po - have deposited a nearly continuous series of clinoform sequences (Trincardi et al., 1994; Correggiari et al., 2005; Cattaneo et al., 2007). Because of the typical cyclonic circulation within the Gulf of Venice, much of the discharged sediment from the Alpine and Apennine rivers has remained on the relatively narrow western shelf or upper slope and drifted longshore southward in response to the southflowing western Adriatic Current, as indicated by the distribution of $\mathrm{Hg}$ - and $\mathrm{Pb}$-rich sediments in the northern Adriatic (compare Fig. 7 with Fig. 5), in part reflecting industrial pollution (Dolenec et al., 1998).

In the southeastern sector of the basin the picture is different, as river discharge from Albania has resulted in a series of lobate deltas, the most prominent being off the Semani and Vjosa rivers (Fouache et al., 2001). However, $\mathrm{Mg}, \mathrm{Cr}, \mathrm{Sc}, \mathrm{Ni}$ and Co distributions in the southern and central parts of the Adriatic (Fig. 7) also suggest that Albanian river sediments have escaped to deeper waters, perhaps via turbidity currents generated during flash floods. The possible importance of such events is supported to some extent by the initial results of integrated wave-ocean-sediment numerical models. Although available measurements have focused mainly on the southwestern Adriatic margin, Carniel et al. (2016b), employing a 1-km coupled wave-ocean-sediment model over the entire Adriatic Sea, found a relatively good match between water and sediment trap samples. This study, on the wake of the work by Harris et al. (2008), suggested that in this transition area, given sufficient data, state-ofthe-art integrated models are capable of describing hyperpycnal sediment fluxes - both in timing and spatial distribution - on the shelf and upper slope.

Time-averaged, vertically integrated water fluxes in the Southern Adriatic Pit region between February 01 and May 31, 2012 (Fig. 8, left) show strong transport-generated dense down-flow within the deepest region of the Bari Canyon. However, a relative maximum driven by a cyclonic circulation is also depicted within the SAP; along the eastern coast, the prevailing direction is northward. Fig. 8 (right panel) shows the vertically integrated sediment fluxes for the same time period. Within the SAP, the relative weight of regional cyclonic circulation, which

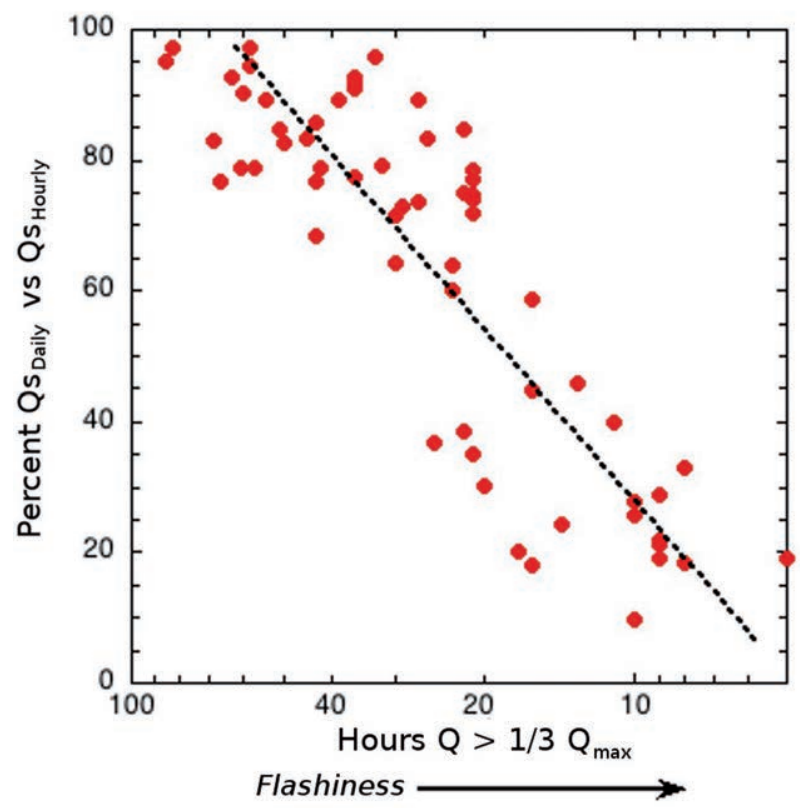

Fig. 6. Comparison of daily sediment loads for small mountainous rivers in Taiwan and southern California computed using daily and hourly water discharges various floods. We define flashiness of a flood as being the time between when water discharge increases from $1 / 3$ peak discharge to peak discharge and back again to $1 / 3$ peak discharge. In this figure, if flashiness is less than 5 hours, calculated sediment loads using daily discharge data tend to account for only $\sim 20 \%$ of the calculated loads using hourly data. When the flashiness index approaches or exceeds 4 days (96 h), such as during snow melt, calculated sediment load based on daily discharge approaches the sediment load based on hourly discharge. Inadequately monitored floods, such as flash floods that can occur in Albania, may thus lead to underestimated calculated sediment discharge if it is based on daily discharge data. 
controls abyssal dynamics on the lower slope and may reach hyperpycnal concentrations, leads to a semi-steady pattern lasting several weeks, and is likely capable of redistributing sediment, oxygen, nutrients and biomass throughout the entire abyssal plain (Fig. 8).

Possible differences in water-mass character entering the SAP have also been recently suggested with regard to the benthic biology. Taviani et al. (2016) reported conspicuous megafaunal sessile communities, including cold-water and sponge habitats, showing an asymmetric distribution in the southern Adriatic, with most diverse and abundant live corals settling the western side, especially in Bari Canyon (Carniel et al., 2016a). These observations are hypothesized to be in response to the seasonal cascading of dense shelf water from the western shelves (Carniel et al., 2016b; Bonaldo et al., 2016), specifically canyons and adjacent areas, which limits excess silting and favoring the trophic web (Taviani et al., 2016). This would also support the different nature and behavior of water entrainment emanating from the eastern sector, e.g., less energetic and more silty.

\section{CONCLUDING REMARKS}

Although dam construction has dramatically changed the quantity of fluvial sediment entering the Adriatic Sea, one can still view the area as having two key point sources of incoming sediment: the northwest, fed by five Alpine rivers, most notably the Po, and the southeast, fed by Albanian rivers, particularly the Semani and Vijose. The hypopycnal character of sediment input to the western Adriatic, combined with line-source input of sediments derived from the Italian Apennine rivers, helps explain the clinoform sequences seen along the western Adriatic. In
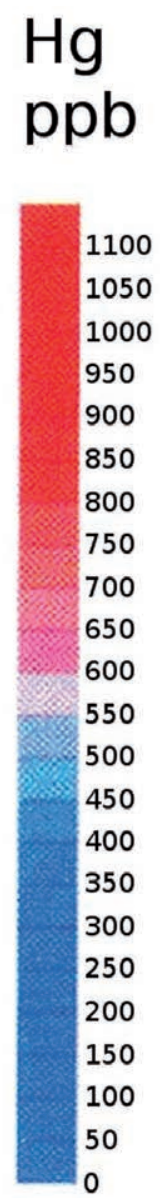

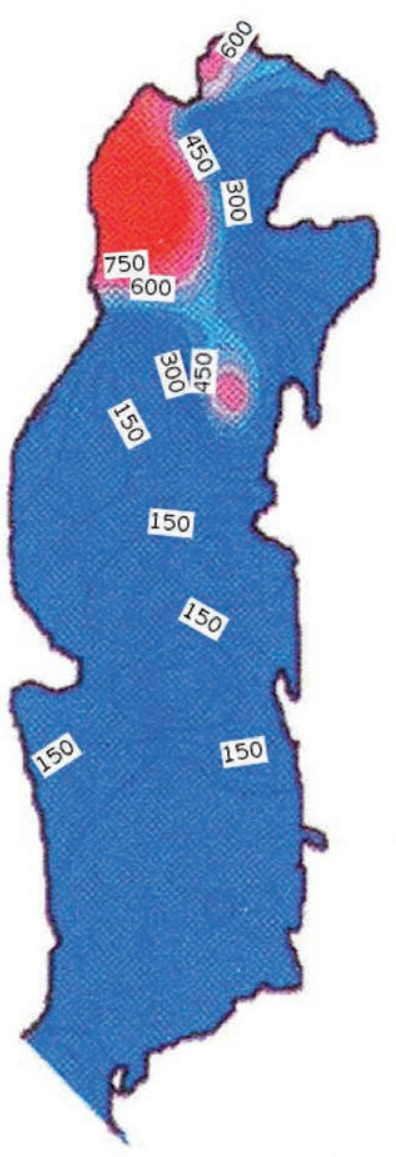

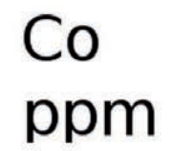

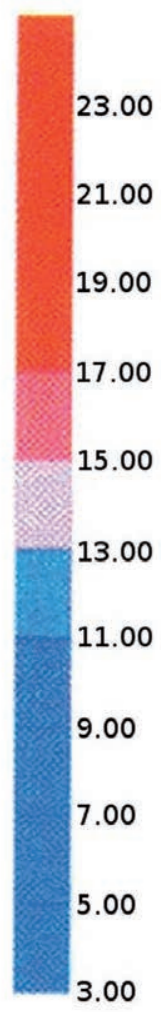

Fig. 7. Distribution of $\mathrm{Hg}$ and $\mathrm{Co}$ in Adriatic Sea sediments (modified from: Dolenec T, Faganeli J, Pirc S, 1998. Major, minor and trace elements in surficial sediments from the open Adriatic Sea: a regional geochemical study. Geol. Croat. 51:59-73) reflect distinct sources. Hg-rich sediments are located seaward of the Po and other Italian Alpine rivers, suggesting relatively little offshore transport. In contrast, Co-rich sediments, presumably derived from Albanian rivers, is spread throughout much of the southern Adriatic, suggesting offshore escape via hyperpycnal turbidity currents. 

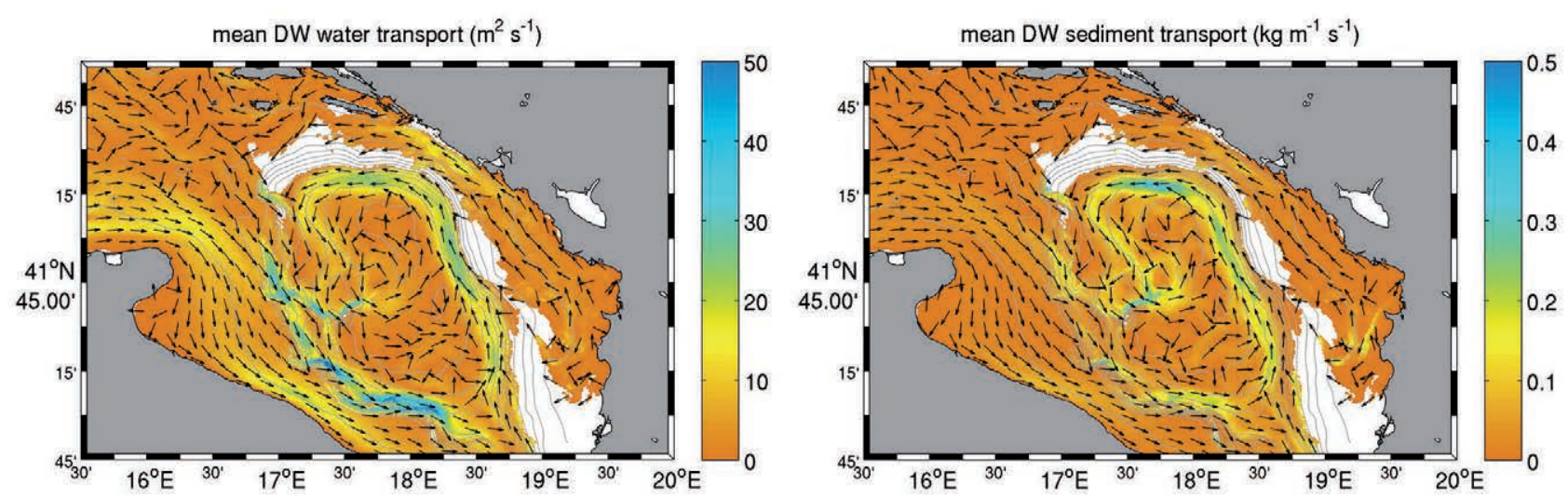

Fig. 8. Vertically integrated water fluxes (left panel) and sediment fluxes (right panel) driven by dense water flow in the Southern Adriatic Pit region. Time-averaged between February 01 and May 31, 2012. Adapted from: Marine Geology, Vol. 375, pages 44-63, 2016, Carniel S, Bonaldo D, Benetazzo A, Bergamasco, Boldrin A, Falcieri FM, Sclavo M, F Trincardi, Langone L, 'Off-shelf fluxes across the southern Adriatic margin: Factors controlling dense-water-driven transport phenomena', with permission from Elsevier.

contrast, because of periodic hyperpycnal discharge and counter-clockwise circulation, Albanian river sediments are transported northward into the central parts of the Adriatic Sea.

Several areas of future research are needed if we are to more fully understand the flux and fate of terrigenous sediments in the Adriatic Sea. First is a better documentation of river-borne sediment. This would include analysis - or reanalysis - of existing data. It may also require obtaining new river data, especially during flash floods. Knowing the difficulty to sample during a sudden flash flood, using an acoustic method might be advisable (Guerrero et al., 2016). Second, such a dichotomy of source and transport as is seen in the Adriatic merits carefully positioned long-cores, ideally based on detailed high-resolution seismic profiles.

\section{ACKNOWLEDGMENTS}

We thank Giuseppe Morabito and Luigi Naselli Flores, for the opportunity they gave JDM to attend the Associazione Italiana di Oceanologia e Limnologia (AIOL) annual meeting. We also acknowledge the CNR Short Term Mobility support grant that allowed JDM to work in Venice. We thank Katherine Farnsworth for her invaluable help in preparing Figs. 3 and 5, as well as T.Y. Lee and J.C. Huang (Taiwan) and J. Warrick (USA) for help in gathering data used in Fig. 6. We thank Francesco Comiti and another anonymous reviewer for their helpful comments on an earlier version of this paper and Massimo Guerrero for our fruitful discussions.

\section{REFERENCES}

Bethge P, 2014. Hydropower struggle: dams threaten Europe's last wild rivers. Spiegel Online In. Available from: http://www.spiegel.de/international/europe/hydropowerdams-threaten-river-wildlife-in-balkans-a-943318.html

Bonaldo D, Benetazzo A, Bergamasco A, Campiani E, Foglini F, Sclavo M, Trincardi F, Carniel S, 2016. Interactions among Adriatic continental margin morphology, deep circulation and bedform patterns. Mar. Geol. 375:82-98.

Carniel S, Benetazzo A, Boero B, Boldrin A, Falcieri FM, Langone L, Sclavo M, Taviani M, Trincardi F, Bonaldo D, 2016a. Interdisciplinary investigation of off- shelf transport in the southern Adriatic Sea: the role of Bari canyon. CIESM Monograph 47:145-156.

Carniel S, Bonaldo D, Benetazzo A, Bergamasco A, Boldrin A, Falcier, FM, Sclavo M, Trincardi F, Langone L, 2016b. Offshelf fluxes across the southern Adriatic margin: Factors controlling dense-water-driven transport phenomena. Mar. Geol. 375:44-63.

Cattaneo A, Trincardi F, Asioli A, Correggiari A, 2007. The Western Adriatic shelf clinoform: energy-limited bottomset. Cont. Shelf Res. 27: 506-525.

Ciavola P, Mantovani F, Simeoni U, Tessari U, 1999. Relation between river dynamics and coastal changes in Albania: an assessment integrating satellite imagery with historical data. Int. J. Remote Sens. 20:561- 584.

Correggiari A, Cattaneo A, Trincardi F, 2005. The modern Po Delta system: Lobe switiching and asymmetric prodelta growth. Mar. Geol. 222:49-74.

De Luque A, Porja T, Martin A, Guijarro JA, Alonso S, 2006. A case of severe flood over Albania: a rainfall analysis from a satellite perspective. Adv. Geosci. 7:65-72.

Dolenec T, Faganeli J, Pirc S, 1998. Major, minor and trace el- 
ements in surficial sediments from the open Adriatic Sea: a regional geochemical study. Geol. Croat. 51:59-73.

Drake DE, Kilpack R, Fischer PJ, 1972. Sediment transport on Santa Barbara-Oxnard shelf, Santa Barbara Channel, California, p. 307-332. In: J.P. Swift, D.B. Duane and O.H. Pilkey (eds.), Shelf sediment transport: processes and patterns. Dowdon, Hutchinson and Ross, Stroudsburg.

Eurosion, 2004. Living with coastal erosion in Europe; sediment and space for sustainability. Part II: Maps and Statistics, DG Environment.

Fouache E, Gruda G, Ucaj S, Nikolli P, 2001. Recent geomorphological evolution of the deltas of the rivers Seman and Vjosa, Albania. Earth Surf. Proc. Land. 26:793-802.

Guerrero M, Latosinski F, Szupiany RN, Nones M, Re M, Gaeta MG, 2015. A sediment fluxes investigation for the 2-D modelling of large river morphodynamics. Adv. Water Resour. 81:186-198.

Guerrero M, Rüther N, Szupiany R, Haun S, Baranya S, Latosinski F, 2016. The acoustic properties of suspended sediment in large rivers: consequences on ADCP methods applicability. Water $8: 13$.

Harris CK, Sherwood CR, Signell RP, Bever AJ, Warner JC, 2008. Sediment dispersal in the northwestern Adriatic Sea. J. Geophys. Res. 113:C11S03.

Inman DL, Jenkins SA, 1999. Climate change and the episodicity of sediment flux of small California rivers. J. Geol. 107: 251-270.

Kao SJ, Milliman JD, 2008. Water and sediment discharge from small mountainous rivers, Taiwan: the roles of lithology, episodic events, and human activities. J. Geol. 116: 431-448.

Milliman JD, Farnsworth KL, 2011. River discharge to the coastal ocean: a global synthesis. Cambridge University Press: $366 \mathrm{p}$.

Milliman JD, Farnsworth KL, Albertin CS, 1999. Flux and fate of fluvial sediments leaving large islands in the East Indies. J. Sea Res. 41:97-107.

Milliman JD, Kao SJ, 2005. Hyperpycnal discharge of fluvial sediment to the ocean: impact of Super- Typhoon Herb (1996) on Taiwanese rivers. J. Geol. 113:503-516.

Milliman JD, Syvitski JPM, 1992. Geomorphic/tectonic control of sediment discharge to the ocean: the importance of small mountainous rivers. J. Geol. 100:525-544.

Mulder T, Savoye B, Piper D, Syvitski J, 1998. The Var sedimentary system: understanding Holocene sediment delivery processes and their importance to the geological record. In: M. Stoker, D. Evans and A. Cramp (eds.), Geological Processes on Continental Margins: Sedimentation, Mass Wasting and Stability. Geological Society of London, Spec. Publication 129:145-166.

Mulder T, Syvitski JPM, 1995. Turbidity currents generated at river mouths during exceptional discharges to the world oceans. J. Geol. 103:285- 299.

Mulder T, Syvitski JPM, Migeon S, Faugères JC, Savoye B, 2003. Marine hyperpycnal flows: initiation, behavior and related deposits. A review. Mar. Petrol. Geol. 20:861-882.

Selenica A, 2004. Flood potential in Albania. Page 94 in Proc. BALWOIS 2004 Conf., Ohrid, Macedonia (abst.).

Simeoni U, Pano N, Ciavola P, 1997. The coastline of Albania: morphology, evolution and coastal management issues. CIESM Publ. 18: 561-168.

Syvitski JPM, Kettner AJ, 2007. On the flux of water and sediment into the Northern Adriatic Sea. Cont. Shelf Res. 27:296-308.

Syvitski JPM, Milliman JD, 2007. Geology, geography and humans battle for dominance over the delivery of fluvial sediment to the coastal ocean. J. Geol. 115:1-19.

Taviani M, Angeletti L, Beuck L, Campiani E, Canese S, Foglini F, Freiwald A, Montagna, P, Trincardi F, 2016. On and off the beaten track: megafaunal sessile life and Adriatic cascading processes. Mar. Geol.y 375:146-160.

Trincard, F, Correggiari A, Roveri M, 1994. Late Quaternary transgressive erosion and deposition in a modern epicontinental shelf: the Adriatic semi-enclosed basin. Geo-Mar. Lett. 12:41-51.

Waananen AO, 1969. Floods of January and February 1969 in central and southern California. U.S. Geological Survey Open File Report: 223 p.

Warrick JA, Milliman JD, 2003. Hyperpycnal sediment discharge from semiarid southern California rivers: Implications for coastal sediment budgets. Geology 31:781-784. 